\title{
Early Stages of Vocal Ontogeny in the Magpie (Pica pica)
}

\author{
Tomás Redondo
}

\section{Introduction}

Much of our knowledge about the ontogeny of bird vocalizations comes from studies on the development of song in oscine birds (Kroonsma \& MıLer 1982). Such studies have revealed a general pattern of song ontogeny across many different species: juvenile birds have non-differentiated precursors of song elements which become gradually modified into their adult-typical configuration through a continuous process of change (MARLER \& Peters 1982). However, compared with the enormous amount of information available on song development in passerines, we know little about the ontogeny of non-song vocalizations (ZANN 1975; BEAVER 1978; COSENS 1981; SMITH 1983; HowEs-Jonks 1984). As a consequence, emphasis on the former topic has probably introduced a source of conceptual bias in our interpretation of the latter. Most studies dealing with the ontogeny of non-song calls in passerines and other avian orders have largely assumed that (i) development consists of a continuous phenomenon in which mature vocalizations arise after a graded process of change, starting from immature vocalizations (Marler 1956; Messmer \& Me Mesmer 1956; LANYOn 1960; MoyniHAN 1962; THOMPSON \& RICE 1970; ZANN 1975; WILKINSON \& HuXIEY 1978); and (ii) that structural variations in the calls at early, non-differentiated stages, make functional sense only in as far as they serve as precursors for later vocalizations (MARLER \& MUNDINGER 1975; WILKINSON \& HUXLEY 1978).

The question of how a behavioural trait develops is usually approached by identifying several stages of the same trait and ordering them in a continuous time sequence. The criterion by which such stages are said to represent different performances of the same trait is two-fold: they share some characteristic structural elements and/or are evoked by the same set of causal factors (GrOOTHUIs 1989). Many studies of call development in birds fail, however, to meet one, and often both, of these requirements: vocalizations arise from earlier ones with no transitional forms between them (Messmer \& Messmer 1956; Thompson \& Rice 1970; Wilkinson \& Huxley 1978; COSENS 1981; Howes-JONES 1984); different developmental stages of the same call (as identified by structural similarities) are frequently associated with different motivational states (MARLER 1956; Messmer \& Messmer 1956; LANYON 1957 in HOWEs-JONES 1984; COSENS 1981; Howes-JonEs 1984); and calls which are included in separate developmental routes at a given age show motivational graduations between them (Messmer \& Messmer 1956; Wilkinson \& Huxiey 1978; Cosens 1981; Meinert \& Bergmann 1983; Thoren \& Bergmann 1987a, b). 
Before understanding why models of song development fail to explain the observed patterns of call ontogeny successfully, more information needs to be gathered on how calls develop and what are they used for by young birds. Studies on behavioural development have long suffered from a theoretical tradition which focused on the adult phenotype as the major target for natural selection, hence overlooked that immature traits may be functional in the short-term, adapted to particular ontogenetic niches (ChisZar 1985; AlberTs \& Cramer 1988; Gomendio 1988). No comprehensive account of developmental patterns can be obtained by ignoring that animals must be functional at all stages of their life cycle (OPPENHETM 1980), so an evolutionary perspective may help us to gain further insight into many problems concerning the ontogeny of behaviour (BEKOFF 1985).

In this paper, I analyze the vocal development of Magpie (Pica pica) nestlings and fledglings from a functional standpoint. Magpies suffer from high mortality rates during the earliest part of their life cycle (REDONDO \& CARRANZA 1989) which, as in most altricial species, appear to be related mainly to the combined effects of predation and starvation (RICKLEFS 1969). Here, I will suggest rather than considering juvenile calls as simple precursors of adult vocalizations, they seem to have evolved as an adaptation to diminish both sources of mortality.

\section{Material and Methods}

Field recordings of magpie nestling calls were conducted at Espiel, Córdoba, during the 1985 and 1987 breeding seasons. Since hatching occurs asynchronously, nestling age was categorized into seven three-days age classes, thus covering the whole nestling period (about 24 days). Recordings from 92 nestlings (38 nests) were obtained in the absence of parents, by using an Uher 4200 Report Monitor tape-recorder through a condenser microphone AKG $568 \mathrm{~EB}$, at $9.5 \mathrm{~cm} / \mathrm{s}$ speed. The behavioural context in which nestling calls were emitted was classified into four categories (begging, resting, crouching and escaping from the nest). Family groups of fledglings were observed for up to eight days after leaving the nest. Sonagrams for a sample of each type of call/nest/day were obtained in a FFT digital sonagraph UNISCAN II 4600. For tonal calls, I measured duration and maximum and minimum frequency of the loudest fundamental band of energy. Frequency modulation in tonal calls appeared like series of V-like valleys. The slope (in $\mathrm{Hz} / \mathrm{ms}$ ) of the initial limb in the steepest valley was measured as an estimate of maximum frequency modulation.

During 1988, 28 nestlings were hand-reared from the time of hatching. In the laboratory, nestlings were kept in artificial (plaster) magpie nests, each containing three to seven nestlings of the same age, in wood boxes with a side entrance under controlled conditions of humidity and temperature. Boxes were placed at $1 \mathrm{~m}$ above ground, allowing nestlings to abandon them easily. I considered that a chick had left the nest when it was found out of the box for three consecutive days. Nestlings were fed every hour from 0800 to 2000 when 1-14 days old and every two hours when older. These feeding rates resembled those observed in the wild (BUITRON 1988). Food supplied to nestlings was a modification of LanYon's (1979) recipe (protein $48.3 \%$ of dry weight), finely homogeneized so as to flow through a $4 \mathrm{~mm}$ canula attached to a syringe. Feeding schedule consisted of serial feeding of nestlings in the same nest, but feeding order changed daily on a rotative basis. Feeding took place in isolation, inside a nést box identical to those in which nestlings were kept, which was equipped with recording ap- 
paratus. I calculated begging rates of nestlings with a short $(1 \mathrm{~h})$ and a long $(2.5 \mathrm{~h})$ food deprivation time as an estimate of their hunger motivation. A positive correlation between fasting time and hunger motivation (measured as the amount of food intake) has been reported in rats (LE MAGNEN 1983). Since hatching, nestlings had become conditioned to a human word as a begging-eliciting stimulus in order to obtain a sufficient number of calls during feeding sessions. Stimulation rate was controlled for as a covariate for comparing begging rates between short and long periods of food deprivation (analysis of covariance, ZaR 1984).

Nineteen nestlings completed their development successfully and were kept in the laboratory for their first week after fledging. They were released once they had managed to feed by themselves in an outdoor aviary.

Nestling growth was determined by fitting fasting body weight (measured prior to the first feeding session) to a logistic model (RrCKLEFs 1983) by a non-linear regression procedure (Statgraph, Statistical Graphics Co., Rockville, Maryland, 1986). The development of thermoregulatory ability was determined according to O'CONNOR (1984). Nestlings were put on clothed Petri capsules and exposed to an ambient temperature of $25^{\circ} \mathrm{C}$ for $30 \mathrm{~min}$. Measurements of cloacal temperature before and after cooling were taken by a cloacal thermometer (Miller \& Weber, Inc.), from which a Thermoregulatory Index can be computed. Adult cloacal temperature was arbitrarily established at $39^{\circ} \mathrm{C}$. Finally, I determined modal ages of appearance of some relevant features related to sensory-motor development: grasping a pencil; balancing on a stick; and opto-motor responses (tracking a circling finger with head movements).

I thank E. CURIO, M. FiCKen and M. Gomendro for helpful criticism of earlier drafts of this paper; L. Arias de ReYNa and coworkers for assistance with field work; A. PACHE and B. PAscual for solving lots of problems at the laboratory, and J. CARRANZA for many facilities during chick rearing and tape analysis. Research funds from Catedra de Biología y Etología, Facultad de Veterinaria, Cáceres, provided partial financial support. During the writing of the paper, the author enjoyed a grant from the Programa de Perfeccionamiento de Doctores y Tecnólogos en España, MEC.

\section{General Development}

\section{Results}

In the wild, newly hatched nestlings usually gaped silently, but vocalizations become frequent when $1-2$ days old. Auditory channels appear fully open at $4-6$ days. Eyes open between 7-10 days. At first, begging is directed upwards and becomes orientated from 12 days onwards. Neossoptiles emerge between $7-10$ days, nestlings appearing fully feathered on dorsal view by day 14. Initial preening movements can be observed as early as 9 days. Neck extension and wing elevation appear at 13 and 19 days, respectively. Flying exercises were first observed at 17 days of age. Figure 1 shows the increase in body weight and thermoregulatory ability, as well as the timing of appearance of some patterns of locomotory coordination in laboratory-reared nestlings. All individual growth curves fitted closely with a logistic model (minimum $\mathrm{F}$ value obtained, $\mathrm{F}=2886, \mathrm{df}=2,28, \mathrm{p}<0.001)$. Mean values of asymptotic weight and intrinsic growth rate were, respectively, $158.4 \mathrm{~g} \pm 7.8795 \% \mathrm{CI}$ and 0.262 days $^{-1} \pm 0.01195 \%$ CI. Maximum weight gain per day occurs at 10.9 days \pm 1.4 SD. Figure 1 also shows that endothermy is poorly developed before 11 days and that coordination of motor patterns improves rapidly between 14 and 20 days. Fledging dates observed in the wild 


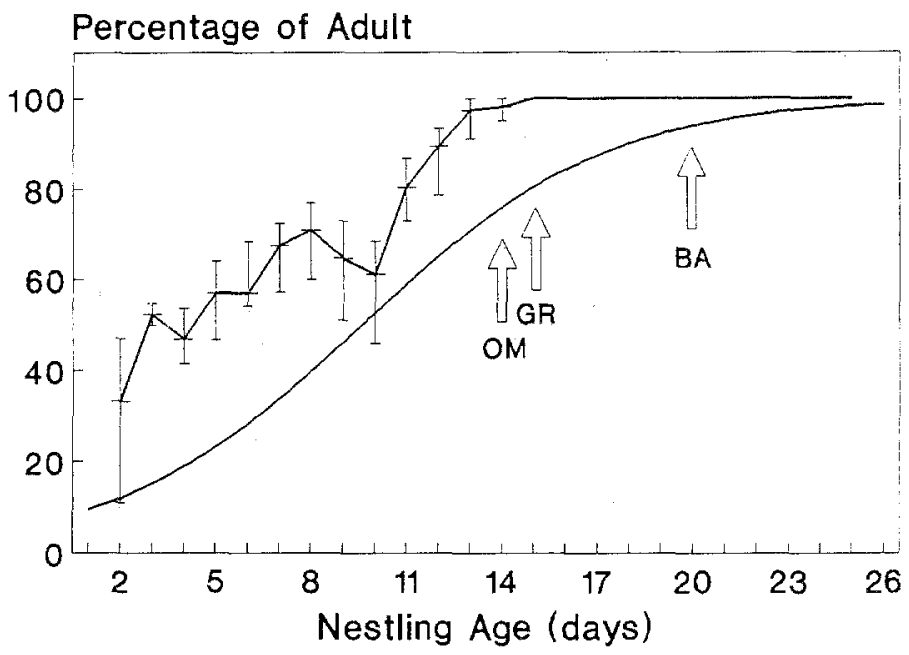

Fig. 1. The development of thermoregulatory ability as a percentage of adult thermoregulatory index and growth curve expressed as percentage of asymptotic weight. Vertical bars around mean values of thermoregulatory index show ranges. Arrows indicate modal ages of appearance of some patterns of locomotory coordination: Optomotor response (OM), Grasping (GR) and Balancing on a stick (BA).

(24 days $\pm 2.6 \mathrm{SD}, \mathrm{N}=25$ nests) were earlier than those obtained in the laboratory ( $26.1 \pm 2.98 \mathrm{SD}, \mathrm{N}=19$ ), the difference being probably explained by premature fledging of wild broods in response to disturbance.

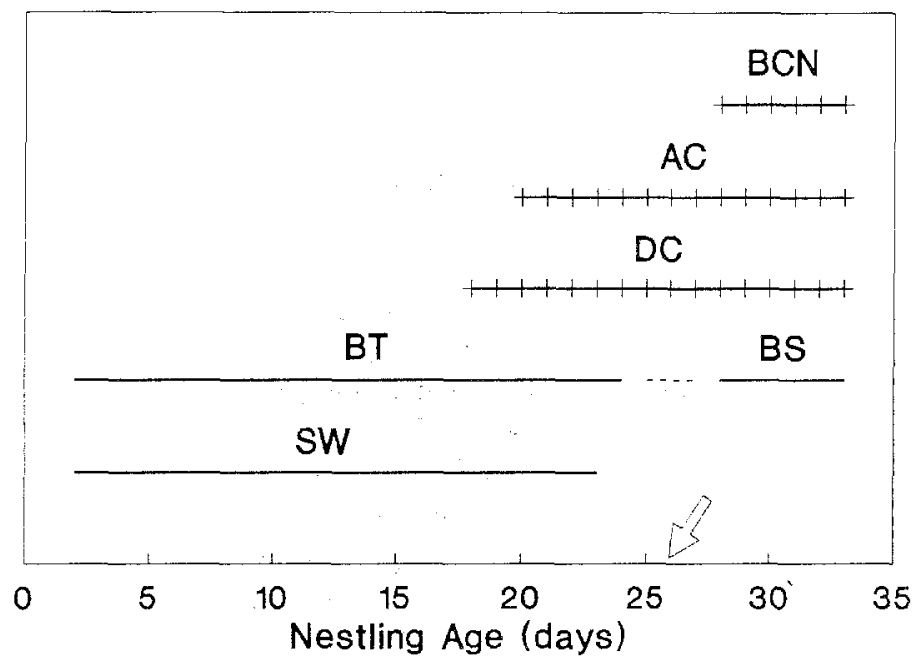

Fig. 2. Ages of occurrence of nestling and fledgling calls. Tonal and harsh vocalizations are denoted by smooth and ticked lines, respectively. SW: Soft Whistle; BT: Begging Trill; BS: Begging Scream; DC: Distress Call; AL: Alarm Call; BCN: Brief Contact Note. The arrow points to mean age of fledging. 


\section{Vocalizations}

The vocal repertoire of wild nestlings consisted of four calls (Fig. 2): Begging Trill, Soft Whistle, Distress Call and Alarm Call. Three of these calls (Begging, Distress and Alarm Calls) remained in the repertoire of fledglings, although Begging Trills changed into Begging Screams at just about the time of leaving the nest. In addition, fledglings also gave Brief Contact Notes. Laboratory-reared nestlings were never observed to give Distress Calls but they uttered all the remaining vocalizations in similar contexts and following similar developmental courses as nestlings observed in the field.
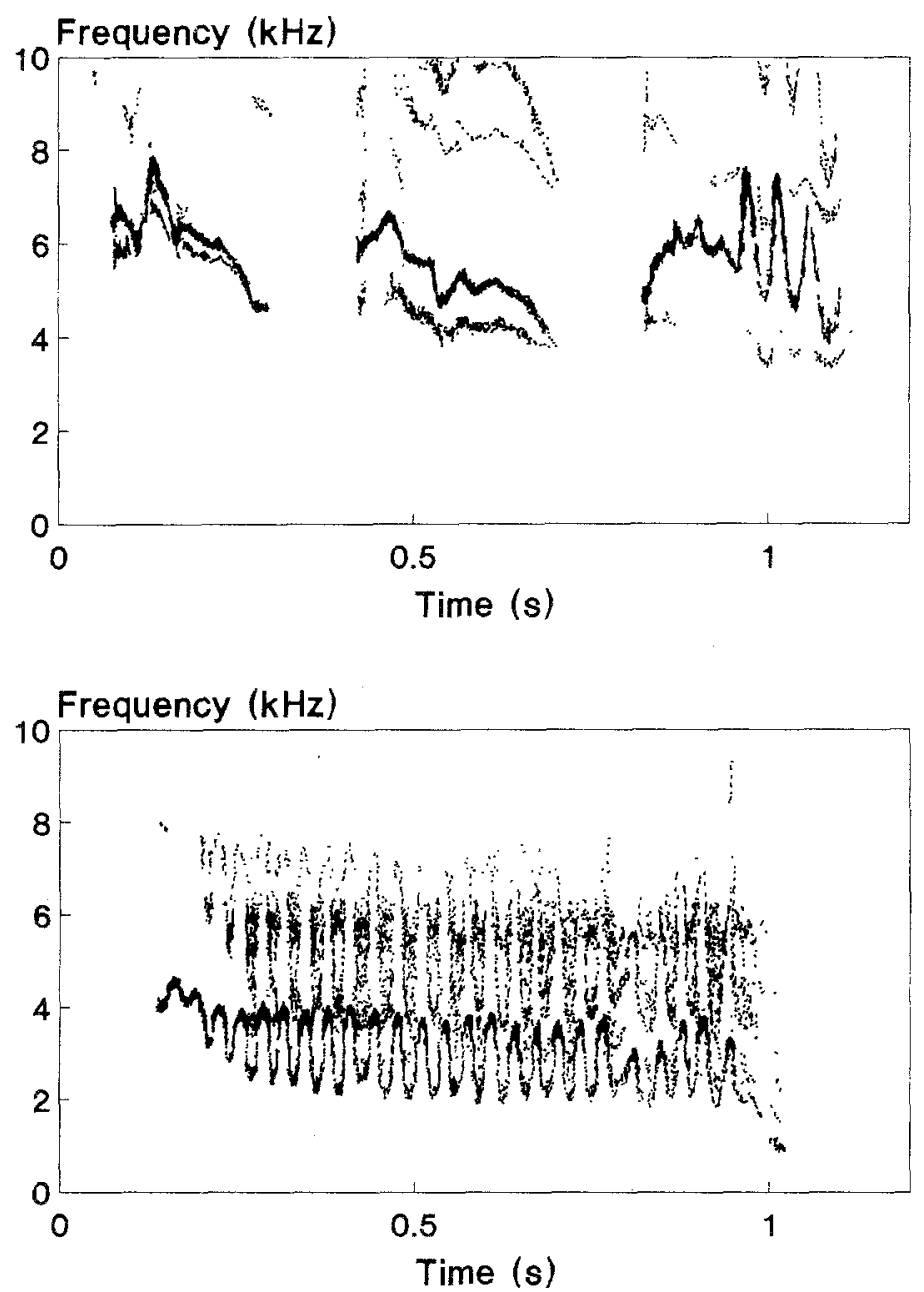

Fig. 3. Upper: Begging Trills of nestlings (left to right) 5, 8 and 11 days old, respectively. Lower: Begging Trill of a nestling 17 days old. 
Begging Trill

These calls had a tonal structure, composed of up to four bands. The first begging calls, recorded when nestlings were 1-2 days old, appeared in the sonagram as inverted $\mathrm{U}$ structures. This simple structure becomes highly complex as nestlings grow older, showing a dramatic increase in duration and frequency-modulation (Fig. 3; Table). To my ear, calls also increased in amplitude with age but no intensity measurement was done. As a result of frequency modulation (FM), energy is widely dispersed along a wide frequency range. This leads to calls becoming increasingly noisier with age, but closer examination of the sonagrams at a lower speed revealed that they still had a tonal quality. This process of increasing duration and FM ends when nestlings are about to leave the nest.

Rates of calling were dependent upon the nestlings' level of hunger motivation. As Fig. 4 shows, begging rates were higher after a $2.5 \mathrm{~h}$ long period of food deprivation than after a $1 \mathrm{~h}$ long period.

Mean values $( \pm S E)$ of maximum and minimum frequency, duration, frequency range and maximum rate of frequency modulation of the dominant fundamental band in Begging Trills (top) and Soft whistles (bottom).

\begin{tabular}{|c|c|c|c|c|c|c|c|c|c|c|}
\hline \multirow[t]{2}{*}{$\begin{array}{l}\text { Age } \\
\text { (days) }\end{array}$} & \multicolumn{2}{|c|}{$\begin{array}{c}\text { FRMNN } \\
(\mathrm{Hz})\end{array}$} & \multicolumn{2}{|c|}{$\begin{array}{l}\text { FRMAX } \\
(\mathrm{Hz})\end{array}$} & \multicolumn{2}{|c|}{$\begin{array}{l}\text { DURATION } \\
(\mathrm{ms})\end{array}$} & \multicolumn{2}{|c|}{$\begin{array}{l}\text { RANGE } \\
(\mathrm{Hz})\end{array}$} & \multicolumn{2}{|c|}{$\begin{array}{c}\text { FM RATE } \\
(\mathrm{Hz} / \mathrm{ms})\end{array}$} \\
\hline & Mean & $\mathrm{SE}$ & Mean & $\mathrm{SE}$ & Mean & $\mathrm{SE}$ & Mean & SE & Mean & SE \\
\hline $1-3$ & 4737 & 120 & 6206 & 125 & 126 & 6.9 & 7674 & 179 & 21.0 & 1.7 \\
\hline $4-6$ & 4689 & 121 & 6691 & 139 & 180 & 10.0 & 8693 & 203 & 22.9 & 1.3 \\
\hline $7-9$ & 3222 & 63 & 5510 & 106 & 307 & 19.4 & 7798 & 207 & 32.5 & 2.3 \\
\hline $10-12$ & 2281 & 58 & 4938 & 234 & 559 & 50.3 & 7594 & 459 & 33.0 & 3.4 \\
\hline $13-15$ & 2331 & 74 & 5226 & 114 & 511 & 34.3 & 8120 & 224 & 46.6 & 4.4 \\
\hline $16-18$ & 1700 & 50 & 4499 & 87 & 701 & 41.6 & 7299 & 167 & 69.9 & 3.9 \\
\hline $\mathrm{F}[1,25]^{1}$ & \multicolumn{2}{|c|}{ 1) $115.1^{1 * * * *}$} & \multicolumn{2}{|c|}{ 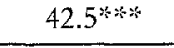 } & \multicolumn{2}{|c|}{$37.2 * * *$} & \multicolumn{2}{|c|}{2.4} & \multicolumn{2}{|c|}{$35.6^{2 * * 2 * 3}$} \\
\hline $1-3$ & 3383 & 402 & 5625 & 497 & 120 & 15.0 & 7867 & 752 & 17.6 & 4.1 \\
\hline $4-6$ & 3529 & 210 & 4627 & 297 & 126 & 13.1 & 5923 & 440 & 12.0 & 1.1 \\
\hline $7-9$ & 3222 & 150 & 4380 & 181 & 129 & 11.5 & 5537 & 262 & 14.4 & 1.4 \\
\hline $10-12$ & 2633 & 164 & 3067 & 217 & 117 & 43.2 & 3.500 & 275 & 9.6 & 5.5 \\
\hline $13-15$ & 2194 & 177 & 2969 & 186 & 237 & 48.2 & 3744 & 323 & 8.7 & 2.3 \\
\hline $16-18$ & 1931 & 102 & 2617 & 134 & 156 & 21.6 & 3303 & 226 & 29.7 & 7.2 \\
\hline $\mathrm{F}[1,14]^{1}$ & \multicolumn{2}{|c|}{ ) $55.5 \%$} & \multicolumn{2}{|c|}{$99.3^{x-2 x+25}$} & \multicolumn{2}{|c|}{$4.8^{*}$} & \multicolumn{2}{|c|}{$56.5^{\text {나나 }}$} & \multicolumn{2}{|c|}{0.2} \\
\hline
\end{tabular}

Comparison between regression lines (analysis of covariance):

Slopes:

F $[1,39]$

3.9

$16.9^{* \cdots * 2}$

Elevations:

$8.5^{* * *}$

$-$

$\mathrm{F}[1,40]$

$90.9^{* * * * k}$

1) Linear regression between mean values per nest per day and nestling age

* $\mathrm{p}<0.05 ;$;*t $\mathrm{p}<0.01 ; * * \mathrm{p}<0.001$. 


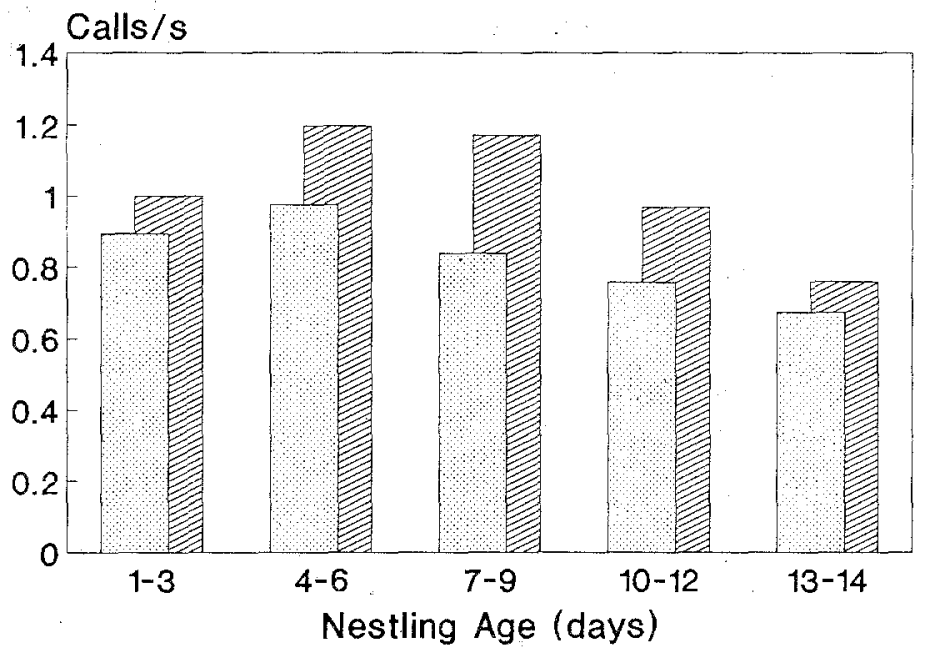

Fig. 4. Adjusted mean values of begging rates while controlling for the effect of stimulation rate as a covariate. Lower values correspond to feeding sessions after a $1 \mathrm{~h}$ period of food deprivation, higher ones to those after a $2.5 \mathrm{~h}$ period (WILCOXON test for comparison of begging rate/stimulation rate between periods, $1-3$ days: $Z=1.89, p<0.05 ; 4-6$ days: $Z=4.45, p<0.001 ; 7-9$ days: $Z=5.83, p<0.001$; $10-12$ days: $Z=2.96, p<0.01 ; 13-14$ days: $Z=2.45, p<0.01)$.

\section{Begging Scream}

When nestlings were about to leave the nest, Begging Trills changed into Begging Screams within a couple of days. The transition between both calls is a gradual process, with calls of intermediate structure appearing in between (Fig. 5). Begging Screams of

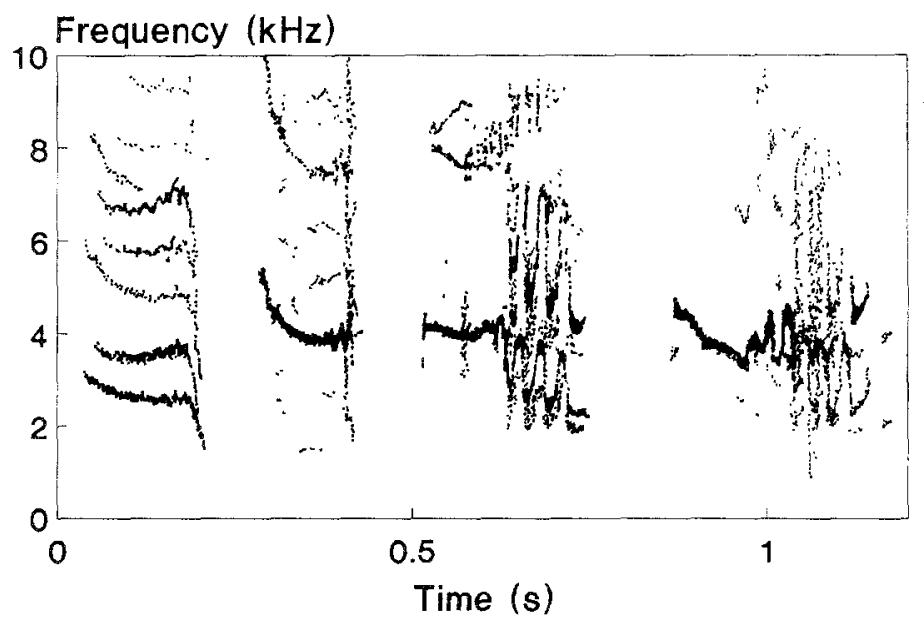

Fig. 5. (Left) Two Begging Screams of fledglings and (right) two transitional forms between Begging Screams and Begging Trills. 
fledglings were of a higher amplitude and shorter duration than nestling Trills and lacked their characteristic FM and energy dispersion. In the laboratory, the transition between calls was a rather sudden event. Typically, a nestling, which previously had not given any signs of change, started to produce Screams prior to the first feeding of the day or after a $2.5 \mathrm{~h}$ period of food deprivation. These calls contained a large amount of intermediate transitional forms. Dates of first appearance of Begging Screams were closely associated with fledging dates (Fig. 6).

Soft Whistle

This vocalization was first recorded when nestlings were $1-2$ days old but became much more frequent between 5 and 11 days. Soft Whistles were given by nestlings while in resting postures and were especially common just after bouts of begging. They could be easily elicited by tactile or auditory stimuli coming from myself or nestmates. Like Begging Calls, Soft Whistles had a tonal structure and sounded like brief, musical notes of very low amplitude. Throughout the nestling period, intermediate gradual calls between Soft Whistles and Begging Trills could be observed during a recording session but such calls were not included in the analyzed samples. Soft Whistles had a lower pitch and were shorter than Begging Trills, and typically lacked their intense FM and broad frequency-range (Fig. 7; Table). In the wild, Soft Whistles were not recorded after 17 days of age. Hand-reared nestlings continued to give brief, soft and low-pitched calls after begging bouts well after this age but these calls readily graded into Begging Calls similar to those given by nestlings with a low hunger motivation. Consequently, I concluded that Soft Whistles represent a characteristic vocalization in the early nestling period.

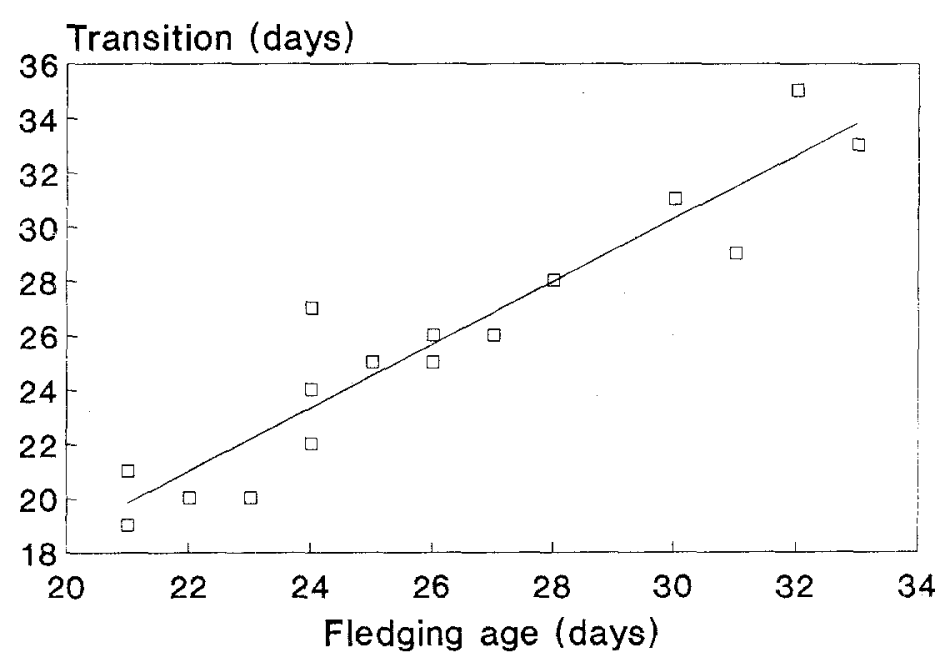

Fig. 6. Age of first appearance of transitional forms between Begging Trills and Begging Screams plotted against fledging age for 19 laboratory-reared nestlings. 
Heft 2
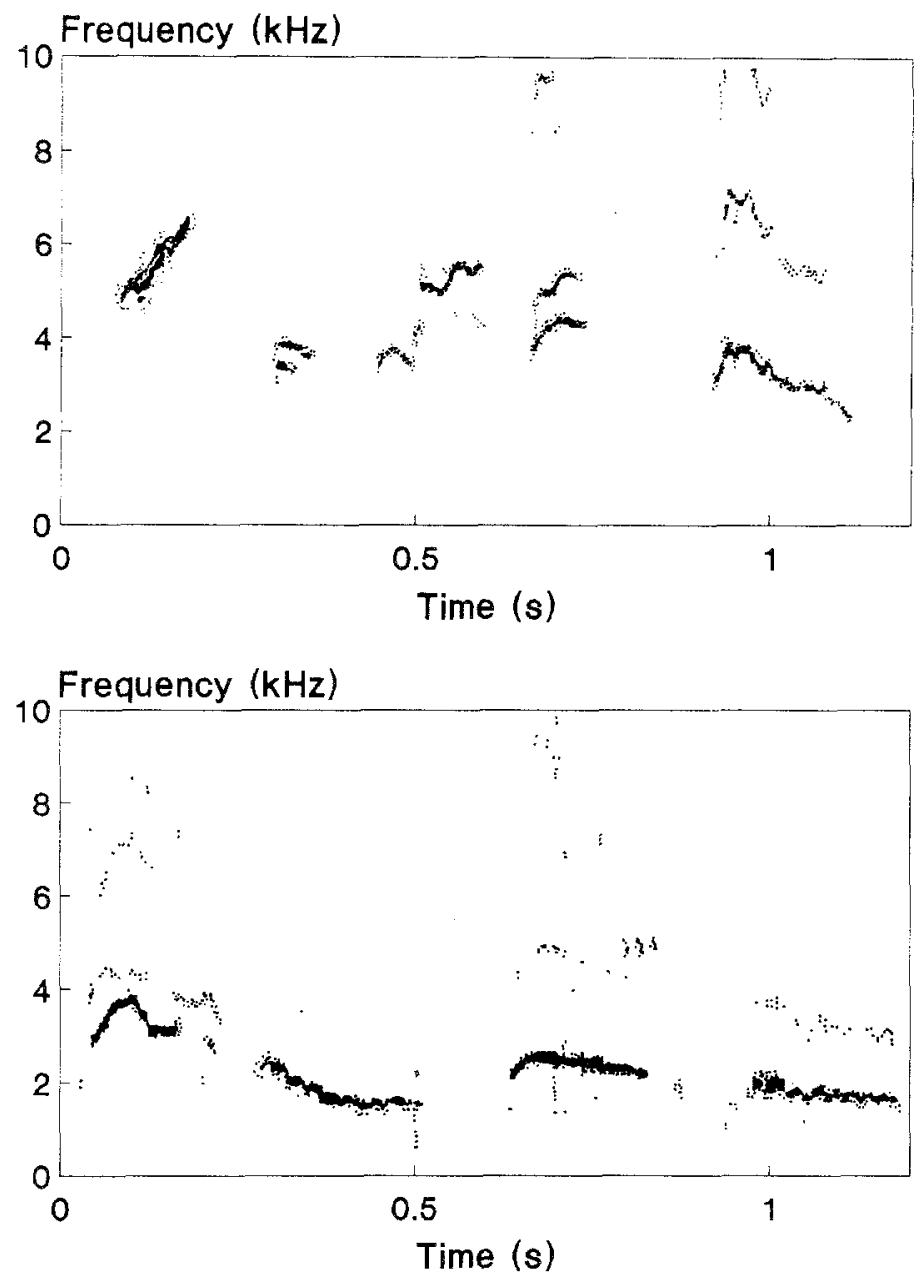

Fig. 7. Upper: Soft Whistles of nestlings (left to right) 2, 5, 5, 8 and 11 days old. Lower: Soft Whistles of nestlings $11,14,14$ and 17 days old.

I considered three hypotheses for the functional significance of this call:

A) Soft Whistles act as a brooding solicitation signal, i.e. they advertise to parents about the cooling of nestlings which are still unable to thermoregulate This hypothesis was supported by the fact that Soft Whistles were triggered by tactile stimuli. In addition, their frequency of occurrence in the wild dropped around the age endothermy develops (11 days) (Fig. 8).

B) Soft Whistles are a satiation signal, as was suggested by the fact that they were frequently uttered after, and graded with, begging bouts. 


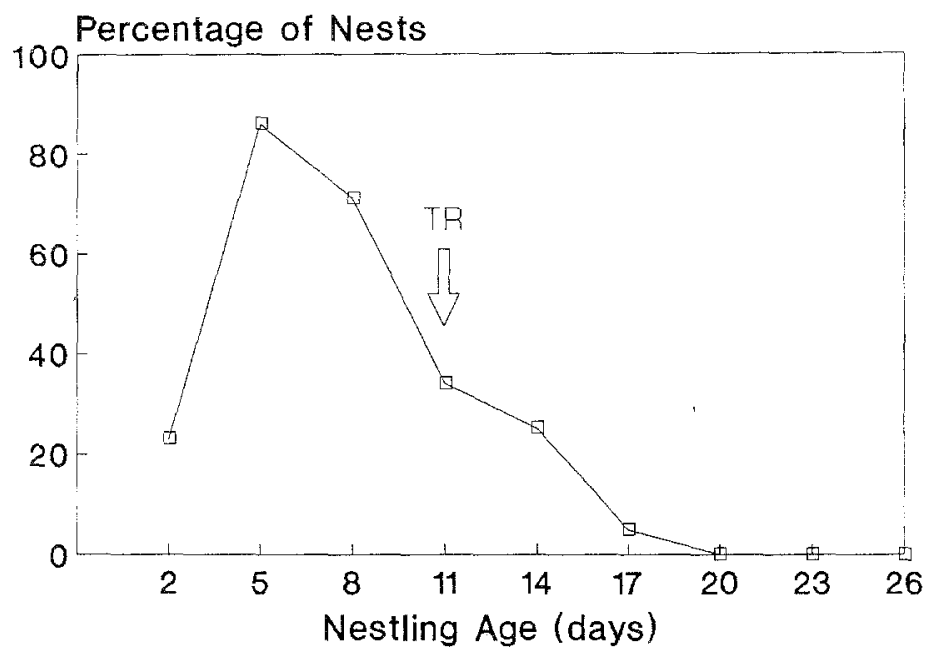

Fig. 8. Percentage of nests of a given age in which nestlings uttered Soft Whistles $(N=24)$. The arrow points to the age at which nestlings show the highest daily gain in thermoregulatory ability.

C) Soft Whistles advertise to parents that nestlings are alive and in good condition. Physical activity of nestlings may provide clues about their condition, but its frequency of occurrence is probably limited due to energetic constraints. This hypothesis was supported by the fact that Soft Whistles were elicited by stimuli coming from the caretaker, mainly during periods of nestling inactivity. In addition, those nestlings which died from pathological processes in the laboratory, completely ceased vocalizations during the period they showed symptoms of illness.

These hypotheses predict that emission rates of Soft Whistles should increase with (i) a decrease in nestlings' body temperature (hypothesis A); (ii) a decrease in hunger motivation at a constant temperature (hypothesis B); and (iii) offspring's awareness of the presence of a caretaker at the nest when both temperature and hunger motivation are held constant (hypothesis $\mathrm{C}$ ).

Hypothesis A was rejected after I observed that during the cooling sessions for determining thermoregulation, the utterance of Soft Whistles was negligible, i.e. cooling in hibited vocalizations. In order to test hypothesis B, I calculated calling rates of nestlings 5-9 days old at nest temperature during 2 min of observation at 20,40, and 60 min after they received the first feeding of the day. Fig. 9 shows that, contrary to the prediction, an increase in hunger motivation actually resulted in an increase in calling rates. Finally, I also calculated calling rates of nestlings $6-7$ days old at nest temperature, $40 \mathrm{~min}$ after they had received the second feeding of the day, during two 2 min periods before and after $10 \mathrm{~s}$ of acoustic stimulation (softly talking to nestlings). Stimulation caused calling rates to increase from $0.70 \pm 0.43 \mathrm{SE}$ to $6.98 \pm 1.05 \mathrm{SE}$ calls per nestling per minute (WILCOXON test, $\mathrm{T}=101.2, \mathrm{p}<0.01, \mathrm{~N}=14$ ). Hypothesis $\mathrm{C}$ also accounts for the fact that Soft Whistles are given mainly between begging bouts 
and at early ages, for they should be prevalent precisely when motor activity is low or poorly developed.

Distress and Alarm Calls

The first truly harsh calls which appeared in the repertoire consisted of Distress Calls given by nestlings at the age of 17 days. These and subsequent calls were uttered when nestlings were seized or handled by us. Fig. 10 shows that energy is distributed through a wide frequency range but it concentrates around $3 \mathrm{kHz}$.

The occurrence of Distress Calls reaches a maximum around 20 days and declines thereafter. This is a consequence of a sudden shift in the anti-predator response of nestlings which occurs at this age. Chicks younger than 20 days typically respond to an intrusion at the nest by crouching and freezing, a passive response which appears when nestlings are 14 days old (REDONDO \& CARRANZA 1989). At about 20 days, nestlings develop an active response to intruders which consists of jumping out of the nest while giving Alarm Calls (Fig. 11). This response may result in premature fledging if nestlings fall down from the nest tree. Alarm Calls are also genuine harsh vocalizations given in series of $1-4$ brief syllables (Fig. 10). Compared with Distress Calls, they show a more uniform pattern of energy distribution, with amplitude peaks around 3 , 6 and $9 \mathrm{kHz}$.

Distress and Alarm calls appear de novo during development. They show no transitional forms with any other call in the repertoire, nor with each other.

Fig. 9. Mean (SE) rates of emission of Soft Whistles by nestlings $5-9$ days old at 20,40 and $60 \mathrm{~min}$ after they had received the first feeding in the day (KRUSKAL-WadLrs test, H $=5.5, \mathrm{df}=2, \mathrm{p}=0.06 ;$ SPEARMAN's correlation coeficient, $r=$ $0.31, \mathrm{p}<0.01, \mathrm{~N}=105$ ).

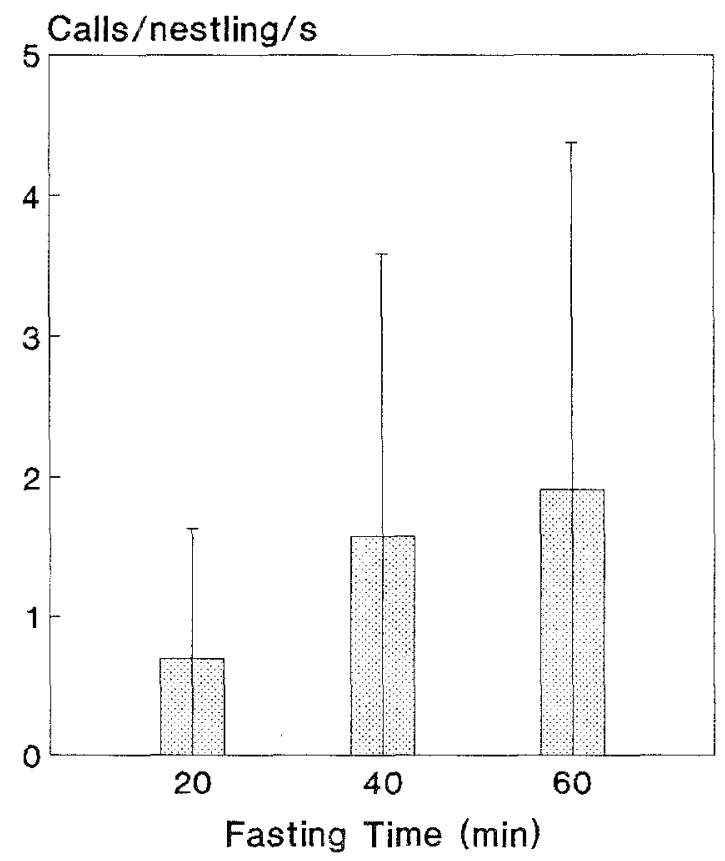



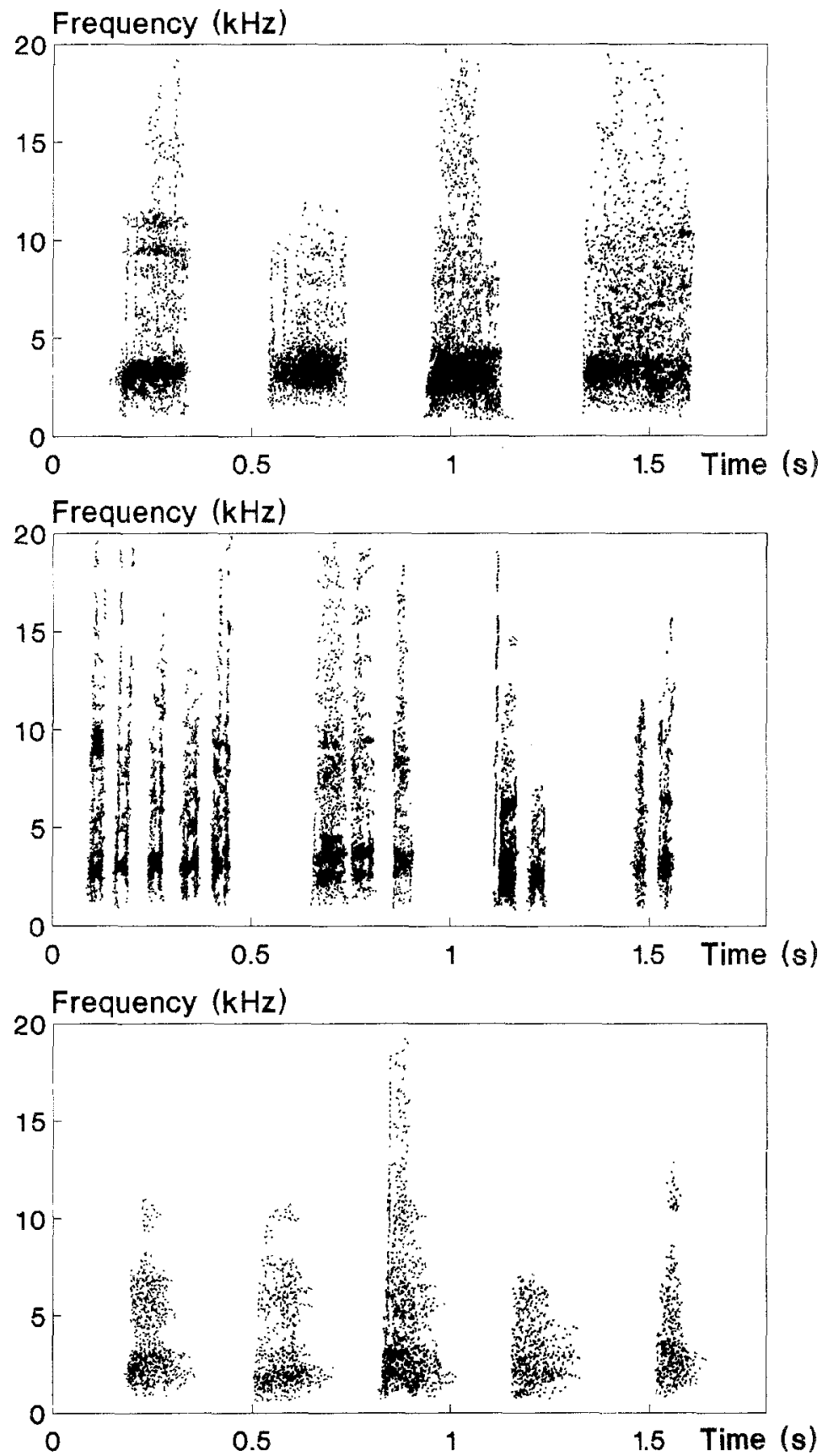

Fig. 10. Harsh vocalizations of fledglings. Upper: four Distress Calls; middle: four Alarm Calls; lower: five Brief Contact Notes. 


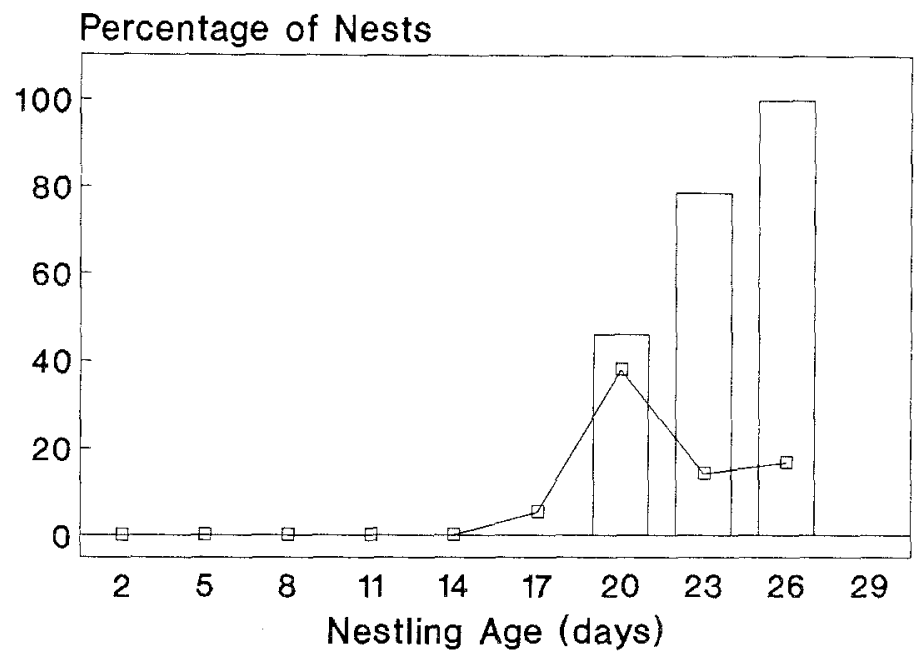

Fig. 11. Percentage of nests of a given age in which nestlings uttered Distress Calls (lines) or Alarm Calls (bars) $(\mathrm{N}=51)$.

Both Distress and Alarm calls were of high amplitude and triggered intense defensive responses in adult birds, especially Alarm Calls. In 4 out of 9 cases, parents increased their scolding rates and approached closer to the nest after nestlings gave only Distress Calls. The comparative figure for Alarm Calls was an increase in defence intensity in 15 out of 18 cases (FISFIER's test, $\mathrm{p}=0.052$ ).

\section{Brief Contact Note}

This is a harsh, low-pitched call of very low amplitude given by fledglings. Fig. 10 shows that the energy is distributed rather uniformly throughout a frequency range of $0.5-10 \mathrm{kHz}$. The onset of the call is abrupt, but energy vanishes smoothly at the end of the call. Like anti-predator calls, Brief Contact Notes appear de novo, without evident transitional forms with preceding calls.

This call was rarely observed in the wild, but laboratory-reared fledglings gave it very frequently, although its occurrence was restricted to calling bouts associated with two behavioural contexts: exploration and play. Exploration and walking was the most frequent context of calling by solitary fledglings. Social play episodes (including hopping, wing fluttering, chasing and pecking others' tail) also included high rates of vocalization.

\section{Discussion}

Five out of the six calls which compose the vocal repertoire are linked either to a context related to feeding (two begging calls and Soft Whistles) or anti-predator defence (Alarm and Distress Calls). These are precisely the two contexts in which parents allocate most of their effort. Compared with other parental activities (like brooding and 
nest sanitation), feeding nestlings and defending them against predators monopolize most of the risk, time and energy budgets of parents (O'CONNOR 1984), their relative contribution to parental duties increasing as the offspring grow older (BUITRON 1988; REDONDO \& CARRANZA 1989). Greater allocation of parental effort towards feeding and protecting nestlings has probably evolved to compensate for the two major ecological sources of nestling mortality: starvation and predation (RICKLEFS 1969). In my study population, about $26 \%$ of the hatched nestlings died from starvation (withinbrood losses) and $34 \%$ were killed by predators $(\mathrm{N}=266)$.

The above considerations suggest that nestling vocalizations may have evolved in response to direct ecological pressures, hence their structural design is expected to be molded by forces related to the ecology of sound propagation. The structure of Begging Trills seems to be a compromise between the neccessities for nestlings to make themselves conspicuous to parents and cryptic to non-intended receivers, like predators (REDONDO \& ARIAS DE REYNA 1988). A wide frequency range may help begging calls to be easily located (ROOKE \& KNIGHT 1977). In addittion, such calls show a high degree of spectral complexity, caused by energy dispersion and FM, which facilitates their degradation into the environment (RICHARDS \& Wiley 1980; CosENS \& Falls 1984). Age-related changes in the structure of Begging Trills involve an increase in both energy dispersion and FM which is likely to compensate for the more detectable (louder, longer and lower-pitched, MARTEN \& MARLER 1977) calls uttered by older nestlings (REDONDO \& EXPOSITO 1990).

When nestlings leave the nest, a sudden (albeit continuous) change occurs in the structure of begging calls. Fledgling Begging Screams are much shorter and louder than nestling Begging Trills and lack their characteristic dispersion of energy. The higher loudness and tonal quality of Begging Screams make them less prone to environmental degradation; hence they retain their structure at longer distances than Begging Trills (Richards \& WILEY 1980). Such a design makes sense in the light of parent-fledgling relationships. Shortly after fledging, chicks await concealed in vegetation for parents to come with food (Butron 1988) but the location of the group of fledglings may change due to spontaneous mobility or as a consequence of disturbances. Fledgling magpies beg for food from any other adult magpie coming nearby but parents recognize and selectively feed their own offspring (IINSDALE 1937), presumably on the basis of an acoustic signature system.

A sudden change in the structure of begging calls at fledging time is a widespread phenomenon. Seven studies (Marler 1956; Thompson \& Rice 1970; ZanN 1975; WINKLER \& SHORT 1978; WILKINSON 1980; BEECHER et al. 1981; HowES-JONES 1984) make explicit that fledgling begging calls gain in tonal quality with respect to preceding nestling calls. The opposite trend is found in two studies (McLaren 1976; THOMpson 1976) while others do not specify the structural changes accompanying the transition between calls (Messmer \& Messmer 1956; HorwiCH 1969; Morehouse \& Brewer 1968; Marler \& Mundinger 1975; Russell \& Balda 1978; Eisacker et al. 1986; more references in HARPER 1986). It is also interesting to note that in species in which acoustic recognition of the offspring is well developed, signature calls are precisely 
fledgling begging calls (Russell \& BALDA 1978; BeECHer et al. 1981; EisACKeR et al. 1986).

There is little doubt that anti-predator nestling calls have evolved as a trait which ensures parental protection (KLUMP \& SHALTER 1984). Theory predicts that parental care should be allocated in direct proportion to the relative reproductive value of the offspring (MILINSKI 1978). Reproductive value of nestlings increases during the nesting cycle (ANDERSSON et al. 1980) and especially shortly before fledging, when chicks develop the ability to escape by themselves from predators (REDONDO 1989). The sensory and motor coordination neccessary to perform a successful escaping response improves greatly between 14 and 20 days, just before the appearance of Alarm Calls. By means of Alarm Calls, nestlings might advertise to their parents about their novel gain in reproductive value (REDONDO \& CARRANZA 1989). In accordance with their function of attracting parents to the nest, anti-predator calls seem to be designed for facilitating detection and location of the source. Both a high amplitude and a concentration of energy in low frequencies improve signal detection (MARTEN \& MARLER 1977). Distress Calls show a clear energy peak around $3 \mathrm{kHz}$, which corresponds to the point of maximal acoustic sensitivity in adults (ROBERTS et al. 1983) and they are efficient over long distances (BREMOND \& AUBin 1990). Alarm Calls have a high frequency range, an abrupt onset and a repetitive structure, all features that make them easily located (RоOKE \& KNIGHT 1977). Since Alarm Calls are given in connection with evasive behaviour, this feature may facilitate a rapid location of endangered nestlings by adults.

The structure of Brief Contact Notes seems to provide clues for allowing source location (abrupt onset and wide frequency range) at short distances (low amplitude and dispersive structure). Brief Contact Notes probably help to maintain the cohesion between siblings during episodes of locomotory activity (like exploration and play), since visual contact is limited within vegetation.

Finally, Soft Whistles function as a kind of very short-range communication. Unlike begging calls, they are not the result of sibling competition for the attention of parents (REDONDO \& ARIAS DE REYNA 1988). Consequently, they seem to be barely locatable (narrow frequency range) and detectable (low amplitude). Calls probably analogous to magpie Soft Whistles are described by THOMPSON \& Rice (1970) and WINKLER \& SHORT (1978).

Developmental variations in the vocal repertoire can be summarized as follows. Early stages are characterized by tonal calls, while late (ca. fledging) phases include noisy calls similar to those of adult birds. The four fledgling calls remain in the adult repertoire with minor modifications (REDONDO \& EXPOSITO 1990). Noisy calls become frequent around 18 days. Before this age, the most frequent vocalizations (Begging Trills) undergo structural changes which make them increasingly noisier as a consequence of intense FM. This sequence of events could be interpreted as if structural changes (FM) in Begging Trills provide nestlings with a mechanism by which they acquire the skill for producing adult noisy calls. However, a detailed analysis of energy dispersion in Begging Trills caused by FM showed that such a process is not probably involved in 
the production of noisy adult calls but probably reduces chances of nestlings being detected by potential predators (REDONDO \& ExPOSITO 1990). In addition, begging calls change their structure at fledging time in a way that can hardly be interpreted in developmental terms (they lack the noisy features of preceding nestling calls) but which is consistent with the novel ecological requirements of fledglings.

The hypothesis that nestling calls act as precursors for late vocalizations is also faced with the problem of discontinuities in the developmental sequence. Both Distress and Alarm Calls and Brief Contact Notes appear de novo, without transitional forms with preceding calls. Also, they are probably controlled by a different set of motivational factors. This is especially clear in the case of begging and anti-predator calls, since those stimuli which elicit fear (crouching) responses actually supress begging (RYDEN 1978; BISCHOF \& LASSEK 1985).

The sudden appearance of vocalizations during development has been widely reported, both in altricial (Marler 1956; Messmer \& Messmer 1956; ThOMPSON \& RICE 1970; Howes-Jones 1984) and precocial species (WILKINSON \& HUXIEY 1978; CosENS 1981). A continuous pattern of late call development starting from begging calls is often invoked (MARLer \& Mundinger 1975; ZANN 1975; Gebauter 1984; HOWES-JONES 1984; EARLE 1986) but, with a single exception, none of these studies provides supporting evidence. Transitional forms between begging and distress calls have been described in the grassfinch Poephila cincta (ZANN 1975). Note, however, that this single case leaves open the question of the nature of the motivational change underlying the transition.

In fact, the transition between begging calls at fledging is the only instance of call ontogeny which fulfills the double criterion of structural and motivational continuity. With respect to the remaining fledgling calls, the rule is a sudden appearance of several call types once the nestlings have left the nest. Such a 'vocal diversification at fledging' is also widely reported (Messmer \& Messmer 1956; ThOMPSON \& RICE 1970; BALPH 1975; ZANN 1975; SMITH 1977; HOWEs-JONES 1984). But, contrary to what is observed at earlier stages of development, there is good evidence for the existence of a continuous pattern of development of adult calls starting from fledgling calls (MARLER 1956; THOMPSON \& RICE 1970; ZANN 1975 and refs. therein; SMITH 1977; HOWESJONEs 1984). Indeed, adult calls in their definitive form may already be present in the repertoire of fledglings (MFssmer \& Messmer 1956; THOMpson \& Rice 1970; ZANN 1975; THOMPSON 1976; Howes-Jones 1984). This suggests that neural mechanisms of some displays may be functional at an early point in ontogeny (SCHLEIDT \& SHALTER 1973; GROOTHUIS 1989), as in the well-known study of ANDREW (1966) about testosterone-induced crowing in young chicks. What is relevant for our discussion is that such findings question whether birds require precursors which are functional at nestling stages for developing adult calls at all.

\section{Summary}

The vocal repertoire of magpie (Pica pica) chicks consists of six calls: Begging Trill (BT), Soft Whistle (SW), Begging Scream (BS), Alarm Call (AC), Distress Call (DC) and Brief Contact 
Note (BCN). Both BT and SW have a tonal structure and their occurrence is restricted to the nestling period. At fledging, there is a gradual change from BT into BS and a sudden appearance of harsh calls similar to those of adult birds (AC, DC, BCN), without evident transitional forms with preceding tonal calls. Both the existence and the structural design of calls seem to be adapted for providing nestlings with immediate benefits linked to the two major chapters of allocation of parental care. Emission rates of BT increase with hunger motivation under laboratory conditions. Their structure suggests that they are easily located but liable to suffer from environmental degradation. BS of fledglings may be more resistant to degradation, a trait which may facilitate the identification by parents of their own offspring. Both AC and DC attract parents to defend the nest against potential predators, and their structure make them to be easily located and detectable at long distances. BCN are given by fledglings during bouts of locomotory activity (exploration and play) and they probably help in maintaining the cohesion of the group under conditions of poor visibility. In accordance, this call may be fairly located at short distances. The function of SW was unclear. It is given during periods of nestling inactivity between begging bouts, and could be easily elicited by tactile and auditory stimuli. After laboratory experiments, it is concluded that SW serve to indicate parents that nestlings are in good condition, hence to benefit from the parental willingness to invest in a brood with high prospects of survival. Since (i) there is a widespread lack of continuity in the development of adult vocalizations starting from nestling calls, and (ii) nestling calls seem to have evolved to provide birds with benefits in the short-term, these facts argue against the prevailing idea that the main function of calls early in ontogeny is to act as precursors of adult vocalizations.

\section{Zusammenfassung}

Das Lautrepertoire von Elsternestlingen besteht aus 6 Lautäußerungen: Betteltrillern (BT), Sanftes Pfeifen (SP), Bettelkreischen (BK), Alarmruf (AR), Angstschreien (AS) und kurzer Kontaktruf (KR). BT und SP sind tonal und treten nur während der Nestlingsperiode auf. Zum Zeitpunkt des Ausfliegens geht BT graduell in BK über und plötzlich treten auch ohne vorausgehende tonale Übergangsformen rauhe Rufe ähnlich denen der Altvögel auf (AR, AS, KR). Sowohl die Existenz als auch die Struktur der Lautäußerungen scheinen als Anpassungen im Zusammenhang mit einer Optimierung der Brutpflege zu interpretieren zu sein. Die Emissionsrate von BT steigt unter Laborbedingungen mit der Hungermotivation. Die Struktur legt nahe, daß BT leicht geortet werden kann, aber auch leicht von der Umgebung verschluckt wird. BS der flüggen Jungen scheint davon weniger betroffen zu sein, so daß die Eltern leichter ihre Jungen identifizieren können. AR und AS veranlassen die Altvögel, ihr Nest gegenüber potentiellen Prädatoren zu verteidigen; die Struktur der Laute begünstigt ihre Ortung und Wahrnehmung über größere Entfernungen. KR werden von den flüggen Jungen bei lebhafter lokomotorischer Aktivität (Exploration, Spiel) geäußert; sie tragen vielleicht dazu bei, die Gruppe auch unter erschwerten optischen Kontaktmöglichkeiten zusammenzuhalten. Die Funktion von SP blieb unklar. SP war während inaktiver Perioden zwischen Bettelverhalten zu hören und konnte leicht durch taktile und akustische Reize ausgelöst werden. Nach Laborexperimenten ist zu schließen, daß SP den Eltern „Wohlbefinder” der Jungen anzeigt und so Bereitschaft zur Investition in eine Brut mit hoher Überlebenswahrscheinlichkeit fördert. Daß (1) zwischen den Rufen der Altvögel und dem Repertoire der Nestlingen weitgehend keine kontinuierlichen Übergänge festzustellen und (2) Nestlingsrufe offensichtlich im Hinblick auf kuzfristige Gewinne zu interpretieren sind, spricht gegen die allgemein vorherrschende Ansicht, das Lautrepertoire in frühen Stadien der Ontogenie sei hauptsächlich ein Vorläufer der Adultlaute. 


\section{Literature}

Alberts, J. R., \& C. P. Cramer (1988): Ecology and experience. Sources of means and meanings of developmental change. In: E. M. BLASs, Handbook of Behavioral Neurobiology 9: 1-39. N. Y. Andersson, M., C. G. WikLund, \& H. Rundgren (1980): Parental defence of offspring: a model and an example. Anim. Behav. 28: 536-542. - ANDrEw, R. J. (1966): Precocious adult behaviour in the young chick. Anim. Behav. 14: 485-500. B BipH, M. H. (1975): Development of young Brewer's blackbirds. Wilson. Bull. 87: 207-230. • BEECHER, M. D., I. M. BEECHER, \& S. HAHN (1981): Parent-offspring recognition in bank swallows (Riparia riparia): II. Development and acoustic basis. Anim. Behav. 29: 95-101. - Bekoff, M. (1985): Evolutionary perspectives of behavioral development. Z. Tierpsychol. 69: 166-167. - BISCHOF, H. J., \& R. LASSEK (1985): The gaping reaction and the development of fear in young zebra finches (Taeniopygia guttata castanotis). Z. Tierpsychol. 69: 55-65. Bremond, J. C., \& T. Aubin (1990): Responses to distress calls by black-headed gulls, Larus ridibundus: the role of non-degraded features. Anim. Behav. 39: 503-511. - Butron, D. (1988): Female and male specialization in parental care and its consequences in black-billed magpies. Condor 90: 29-39. CHISZAR, D. (1985): Ontogeny of communicative behaviors. In: E. S. Gollin, The Comparative Development of Adaptive Skills: Evolutionary Implications: 207-238. Hillsdale. - CosEns, S. E. (1981): Development of vocalizations in the American Coot. Can. J. Zool. 59: 1921-1928. • Ditto \& J. B. Falls (1984): A comparison of sound propagation and song frequency in temperate marsh and grassland habitats. Behav. Ecol. Sociobiol. 15: 161-170. - Elsacker, L. van, R. PinXten, \& R. Verheyen (1986): Parent-offspring recognition in starlings (Sturnus v. vulgaris). In: L. PASSERA, \& J. P. LACHAUD, The Individual and Society: 73-78. Toulouse. EARLE, R. A. (1986): Vocalizations of the South African Cliff Swallow Hirundo spilodera. S. Afr. J. Zool. 21: 229-232. - GEBAUER, A. (1984): Die Lautentwicklung beim Buntspecht, Dendrocopos major. Ann. Orn. 8: 107-127. - Gomendio, M. (1988): The development of different types of play in gazelles: implications for the nature and functions of play. Anim. Behav. 36: 825-836. - GroonHuIs, T. (1989): On the ontogeny of display behaviour in the black-headed gull: $\mathrm{I}$. The gradual emergence of the adult forms. Behaviour 109: 76-124. - HARPER, A. B. (1986): The evolution of begging: sibling competition and parent-offspring conflict. Am. Nat. 128: 99-114. - HoRwich, R. H. (1969): Behavioral ontogeny of the mockingbird. Wilson Bull. 91: 434-440. - Howes-Jones, D. (1984): The vocal behaviour of young warbling vireos. Can. J. Zool. 62: 205-230. Klump, G. M., \& M. D. Shalter (1984): Acoustic behaviour of birds and mammals in the predator context: I. Factors governing the structure of alarm signals. II. The functional significance and evolution of alarm calls. Z. Tierpsychol. 66: 189-226. - LANYON, W. E. (1960): The ontogeny of vocalizations in birds. In: W. E. LANYON, \& N. N. TAVOLGA, Animal Sounds and Communication: $321-347$. Publ. No. 7. Am. Inst. Biol. Sci. Washington. - Ditto (1979): Development of song in the wood thrush (Hylocichla mustelina), with notes on a technique for hand-rearing passerines from the egg. Am. Mus. Novit. 2666: 1-27. - LE MaGnen, J. (1983): Body energy balance and food intake: a neuroendocrine regulatory mechanism. Physiol. Rev. 63: 314-386. - Linsdale, J. M. (1937): The natural history of magpies. Pac. Coast Avif. 25: 1-234. - McLaren, M. A. 1976. Vocalizations of the boreal chickadee. Auk 93: 451-463. - MARLER, P. (1956): The voice of the chaffinch and its function as a language. Ibis 98: 231-261. - Ditto \& P. C. Mundnnger (1975): Vocalizations, social organization and breeding biology of the twite (Acantbis flavirostris). Tbis 117: 1-17. - Ditto \& S. Peters (1982): Subsong and plastic song: their role in the vocal learning process. In: D. E. Kroodsma, \& E.H. Miller, Acoustic communication in birds Vol 2, 25-50. N. Y. - Marten, K., \& P. Marler (1977): Sound transmission and its significance for animal 
vocalizations. I. Temperate habitats. Behav. Ecol. Sociobiol. 2: 271-290. - MEINERT, U., \& H.-H. BERGMANN (1983): Zur Jugendentwicklung der Lautäußerungen beim Birkhuhn (Tetrao tetrix). Behaviour 85: 242-259. - Messmer, F., \& E. Messmer (1956): Die Entwicklung der Lautäußerungen und einiger Verhaltensweisen der Amsel (Turdus merula merula L.) unter natürlichen Bedingungen und nach Einzelaufzucht in schalldichten Räumen. Z. Tierpsychol. 13: 341-441. - MLLINSKI, M. (1978): Kin selection and reproductive value. Z. Tierpsychol. 47: 328-329. - Morehouse, E. L., \& R. Brewer, (1968): Feeding of nestling and fledgling eastern kingbirds. Auk 85: 44-54. - Moynhan, M. (1962): Hostile and sexual behavior patterns of South American and Pacific Laridae. Behaviour Suppl. 8: 1-365. - O'ConNor, R. J. (1984): The growth and development of birds. Chichester. - Oppenherm, R. W. (1980): Metamorphosis and adaptation in the behaviour of developing organisms. Devl. Psychobiol. 13: 353-356. - REDONDO, T. (1989): Avian nest defence: theoretical models and evidence. Behaviour 111: 161-195. - Ditto \& L. ARLAS DE REYNA (1988): Locatability of begging calls in nestling altricial birds. Anim. Behav. 36: 653-661. - Ditto \& J. Carranza (1989): Offspring reproductive value and nest defense in the magpie. Behav. Ecol. Sociobiol. 25: 369-378. - Ditto \& F. Exposito (1990): Structural variations in the begging calls of nestling magpies (Pica pica) and their role in the development of adult voice. Ethology 84: 307-318. RICHARDS, D. G., \& R. H. WILEY (1980): Reverberations and amplitude fluctuations in the propagation of sound in a forest: implications for animal communication. Am. Nat. 115: 381-399. - Ricklefs, R. E. (1969): An analysis of nesting mortality in birds. Smithson. Contr. Zool. 9: 1-48. • Ditto (1983): Avian postnatal development. In: D. S. Farner, J. R. King, \& K.C. Parkes, Avian Biology 7: 1-83. N. Y. - Roberts, J., Moreno, A., Kacelnik, A., \& M. Hunter (1983): Physical considerations in the frequency limits of birdsong. Acoustic Letters 6: 100-105. - Rooke, I. J., \& T. A. KNIGHT, (1977): Alarm calls of honeyeaters with reference to locating sources of sound. Emu 77: 193-198. • RusseLl, P., \& J. H. BALDA, (1978): The care of young piñon jays and their integration into the flock. J. Orn. 119: 146-171. - Ryden, O. O. (1978): Differential responsiveness of great tit nestlings, Parus major, to natural auditory stimuli. Z. Tierpsychol. 47: 236-253. - SchlerDT, W. M., \& M. D. Shalter (1973): Stereotypy of a fixed action pattern during ontogeny in Coturnix cotur. nix coturnix. Z. Tierpsychol. 33: 35-37. - SMITH, S. M. (1977): The behavior and vocalizations of young turquoise-browed motmots. Biotropica 9: 127-130. - Ditto (1983): The ontogeny of avian behaviour. In: D. S. Farner, King, J. R., \& K. C. PArKes, Avian Biology 7: 85-160. N. Y. - Thompson, W. L. (1976): Vocalizations of the lazuli bunting. Condor 78 : 195-207. - Ditto \& J. O'H. RrCe (1970): Calls of the indigo bunting, Passerina cyanea. Z. Tierpsychol. 27: 35-46. - THOREN, B. ten, \& H.H. BERgManN (1987 a): Veränderung und Konstanz von Merkmalen in der jugendlichen Stimmentwicklung der Nonnengans (Branta leucopsis). Behaviour 100: 61-91. - Ditto (1987 b): Die Entwicklung der Lautäußerungen bei der Graugans (Anser anser). J. Orn. 128: 181-207. - Wilkinson, R. (1980): Calls of nestling chaffinches Fringilla coelebs: the use of two sound sources. Z. Tierpsychol. 54: 346-356. - Ditto \& C. R. HuXley (1978): Vocalizations of chicks and juveniles and the development of calls in the Aldabra white-throated rail Dryolimnas cuvieri aldabranus (Aves: Rallidae). J. Zool. Lond. 186: 487-505. - W WNKLeR, H., \& L. L. SHORT (1978): A comparative analysis of acoustical signals in pied woodpeckers (Aves, Picoides). Bull. Am. Mus. Nat. Hist. 160: 1-110. - ZANN, R. (1975): Inter- and intraspecific variation in the calls of three species of grassfinches of the subgenus Poephila (Gould) (Estrildidae). Z. Tierpsychol. 39: 85-125. - Zar, J. H. (1984): Biostatistical Analysis. Prentice Hall, New Jersey.

Author's address: Estación Biológica de Doñana, C.S.I.C., Apartado 1056, E-41080, Sevilla, Spain 